\title{
Solidarity Fishing - Spear Fishing of Alien Fish Feeds People
}

\author{
João P. Barreiros ${ }^{1 *}$, Dário Ponte ${ }^{2}$, Cristina Santos ${ }^{2}$ and João Medeiros ${ }^{1,2}$ \\ ${ }^{1}$ CE3C - Centre for Ecology, Evolution and Environmental Changes / Azorean Biodiversity Group and Faculty of Agrarian and Environmental Sciences, \\ University of the Azores 9700-042 Angra do Heroísmo, Portugal \\ ${ }_{2}^{2}$ João Medeiros Unipessoal Lda. Parque Industrial de Angra do Heroísmo, Lote 1, 9700-135 Angra do Heroísmo, Portugal.
}

\begin{abstract}
Received: October 21, 2016; Accepted: October 28, 2016; Published: October 31, 2016
*Corresponding author: João P. Barreiros, CE3C - Centre for Ecology, Evolution and Environmental Changes / Azorean Biodiversity Group and Faculty of Agrarian and Environmental Sciences, University of the Azores 9700-042 Angra do Heroísmo, Portugal. E-mail: joao.ps.barreiros@uac.pt
\end{abstract}

In a previous paper by [1], the complex and apparently uncontrollable problem of Lionfish invasion is thoroughly discussed. Selectiveness of spear fishing is highly effective and does allow catches targeting invasive species such as the - very good eating - lionfish. In fact, recent initiatives in the Azores islands have provided fish for poor people in appreciable quantities (Figure 1) by just gathering fishermen and donating catches either to public or private institutions.

A project called "Diving for a Cause" [2] promotes occasional meetings of spear fishers to donate their catches to people under social assistance or poverty. The Azorean regional project "Atlântico Solidário" [3] started in 2009 and is now organizing several actions of this kind through the whole of Portugal.

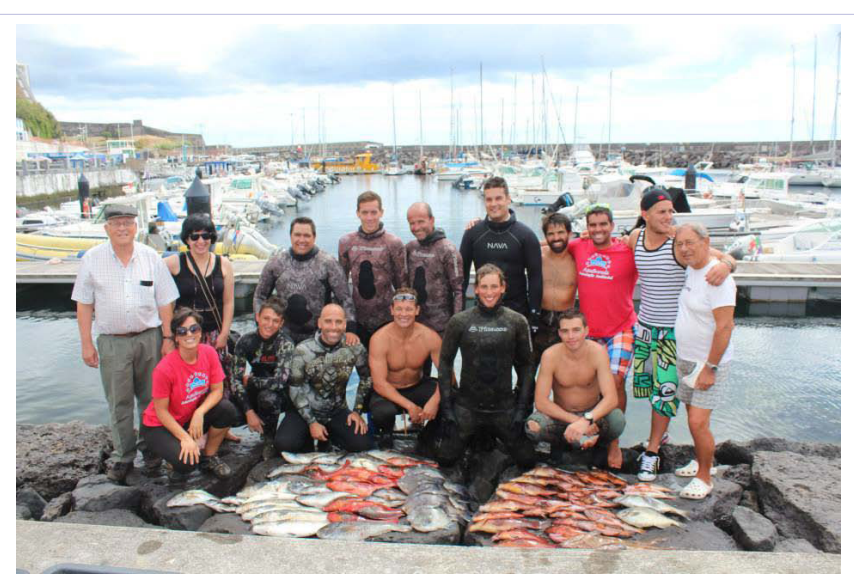

Figure 1: A solidarity spear fishing group from Terceira Island, Azores (NE Atlantic) where ca. $120 \mathrm{~kg}$ of fish were donated to two solidarity institutions by volunteer spear fishers (September 9, 2013). Photo by Marcolino Candeias
All over the Eastern Mediterranean Lessepsian invaders have almost wiped out from many places a number of native species at a very fast rhythm [4]. Most affected countries within this area are promoting active fishing of alien species and in fact, a lot of what is sold in fish markets are indeed invaders from the Red Sea [5]. This also adds valuable protein to many people who otherwise would have little or no access to it at all.

Fishing alien species such as these will also have a positive impact in reducing some populations and allow native species to recover while also extend fishing for local inhabitants. This approach is being tested with success regarding the spread of the alien Scorpion fish in the Caribbean.

This is a simple, cheap and innovative way of connecting science, controlling invasive species and, perhaps even more important, to provide high valued protein to people that would otherwise endure great difficulties in getting this kind of food.

\section{References}

1. C. Pala. As lionfish invade, divers defend threatened ecosystems. Science. 2014;343(6171):591. doi: 10.1126/science.343.6171.591.

2. Diving for a Cause: 2016. [Online] Available from https://www. divingforacause.org/

3. Atlântico Solidário; 2016. [Online] Available from: https://www. facebook.com/AtlanticoSolidario/?ref=page_internal

4. Nunes AL, Katsanevakis S, Zenetos A, Cardoso AC. Gateways to alien invasions in the European seas. Aquatic Invasions. 2014;9(2):133144. http://www.aquaticinvasions.net/2014/Supplements/AI_2014_ Nunes_etal_Supplement.xls

5. EastMed. Report of the technical meeting on the Lessepsian migration and its impact on Eastern Mediterranean fishery. GCP/INT/041/EC GRE - ITA/TD-04. 2010;138.

Citation: Barreiros JP, Ponte D, Santos C, Medeiros J (2016) Solidarity Fishing - Spear Fishing of Alien Fish Feeds People. Int J Marine Biol Res 1(1): 1-1. DOI: http://dx.doi.org/10.15226/24754706/1/2/00106 